\title{
Genetic assessments of breast cancer risk that do not account for polygenic background are incomplete and lead to incorrect preventative strategies
}

\author{
George B. Busby, Paul Craig, Nesrine Yousfi, Saurabh Hebbalkar, Paolo Di
} Domenico and Giordano Bottà

Allelica Inc., New York

Abstract

Breast cancer is the most common cancer among women and is a leading cause of cancer mortality worldwide. There is a significant genetic component to breast cancer risk which is the result of both rare pathogenic mutations and common genome-wide variation. However, the penetrance of pathogenic mutations varies widely and their frequency is low, both at a population level and amongst breast cancer cases. Polygenic risk scores, which aggregate the effect of hundreds to millions of common genome-wide variants offer a way to further understand the contribution of genetics to disease risk. Here we analyse genome-wide data from 221,479 women and 90,307 high coverage exomes to understand how rare and common variation affect lifetime breast cancer risk. We show that PRS strongly modulates the penetrance of mutations in 8 breast cancer susceptibility genes. For example, lifetime risk in $B R C A 1$ carriers with low polygenic risk is almost one third that of carriers with high PRS ( $26 \% \vee 69 \%$ in the bottom and top PRS deciles, respectively). Adding family history of breast cancer provides additional stratification on the potential outcome of disease in carriers of rare mutations. PRS also identifies a significant fraction of the population at equivalent risk to carriers of moderate impact pathogenic variants and who are an order of magnitude more common at a population level. These results have important implications for breast cancer risk mitigation strategies, indicating that the genetic risk of breast cancer is determined by both monogenic mutation and polygenic background, and that assessments of genetic risk for breast cancer risk that do not consider the polygenic background are imprecise and unreliable. 
medRxiv preprint doi: https://doi.org/10.1101/2021.08.13.21262050; this version posted August 23, 2021. The copyright holder for this preprint (which was not certified by peer review) is the author/funder, who has granted medRxiv a license to display the preprint in It is made available under a CC-BY-NC-ND 4.0 International license

\section{Main Text}

Genetic testing for the presence of pathogenic mutations is an established medical practice ${ }^{1}$. However, whilst screening can identify women who are genetically susceptible to breast cancer (BC), two central challenges remain. The first is that pathogenic mutations are rarely completely penetrant, so the presence of a mutation does not always lead to disease ${ }^{2}$. Even for carriers of mutations in the $\mathrm{BC}$ susceptibility genes with the highest risk, penetrance ranges from $47 \%$ to $66 \%$ for $B R C A 1$ and $40 \%$ to $57 \%$ for $B R C A 2^{3}$, meaning that around a third to a half of the women who carry a $B R C A 1 / 2$ mutation will not go on to develop BC. For moderate risk BC susceptibility genes such as PALB2, penetrance estimates are lower, between $26 \%$ and $46 \%{ }^{4}$, and carriers of mutations in low risk BC susceptibility genes such as CHEK2 and ATM have a roughly two fold increased risk compared to non-carriers ${ }^{5,6}$. Family history of $\mathrm{BC}$ also increases risk by around two times in the absence of other risk factors and further increases penetrance in pathogenic mutation carriers ${ }^{7,8}$. Understanding the additional factors that contribute to modulating the penetrance of variants in these genes is critical to evaluating their clinical utility.

The second challenge is that pathogenic mutations in BC susceptibility genes are rare, both at a population level and among cases. In general, the frequency of a pathogenic mutation is negatively correlated with the risk it confers, so those variants that increase risk the most - and are therefore more penetrant - are rarer in the population ${ }^{9}$. Estimates of mutation prevalence in 12 major BC susceptibility genes from population-based analyses, which are subject to less selection bias than analyses of pedigrees, are around $5 \%$ across all 12 genes in BC cases and $1.5 \%$ in non-cases ${ }^{9-12}$. At an individual gene level, frequencies range from around $0.11 \%$ in $B R C A 1$ and PALB2, $0.25 \%$ in BRCA2, to $0.41 \%$ in $A T M$ and $C H E K 2{ }^{11}$. Therefore, screening for rare pathogenic mutations will only ever identify a small subset of those at heightened genetic risk of BC.

To address these critical challenges we analysed data from the UK Biobank to ask two questions. First, does incorporating polygenic background to lifetime risk assessments for $\mathrm{BC}$ in mutation carriers help explain the incomplete penetrance of these mutations. Second, does polygenic risk provide an additional source of genetic risk that can be used to identify women at high risk of BC in the absence of rare pathogenic mutations. 
medRxiv preprint doi: https://doi.org/10.1101/2021.08.13.21262050; this version posted August 23, 2021. The copyright holder for this preprint (which was not certified by peer review) is the author/funder, who has granted medRxiv a license to display the preprint in It is made available under a CC-BY-NC-ND 4.0 International license.

We began by building a new Polygenic Risk Score (PRS) for BC using Training data (summary statistics) from a large Genome-Wide Association Study of $\mathrm{BC}^{13,14}$, together with separate and independent PRS Validation ( $N=72,421 ; 4,777$ BC cases) and PRS Testing ( $N=160,469 ; 10,915$ BC cases) datasets of self-identified White British individuals from the UK Biobank ${ }^{15}$ and phenotypes defined in Supplementary Table 1. We applied Allelica's DISCOVER module ${ }^{14}$ that assesses the performance of 10 different PRS algorithms resulting in a best performing panel that used the Stacked Clumping and Thresholding algorithm ${ }^{16}$. The resulting panel (Allelica 577k) comprised 577,113 genome-wide variants and had increased predictive performance compared with a commonly used 313 variant BC PRS ${ }^{17}$ on the same PRS Testing dataset (Area Under the Receiver Operator Curve (AUC): Allelica 577k = $0.71(95 \% \mathrm{Cl} 0.698-0.717)$; Mavaddat $313=0.68(95 \% \mathrm{Cl}$ 0.669-0.688); Odds Ratio per standard deviation: Allelica $577 \mathrm{k}=1.81(95 \% \mathrm{Cl} 1.78-1.84) ;$ Mavaddat $313=1.56(95 \% \mathrm{Cl}$ $1.53-1.58))$.

Next, we used whole exome sequence data to identify carriers of likely pathogenic / pathogenic variants (LP/P) according to ClinVar $^{18}$ in 90,307 self-identified British ancestry women in the UK Biobank $^{19}$ (Supplementary Tables 2 and 3 ). After removing individuals with prevalent $B C(N=6,322)$, we constructed a separate Cox proportional hazards model for each of 8 BC susceptibility genes using BC case status, age of enrollment and age of disease in the survival function, and carrier status, PRS, family history, 4 principal components of ancestry and genotyping array as covariates. For comparison, we built an equivalent model using all women in the PRS Testing dataset that did not include carrier status. We used these models to predict lifetime risk for each percentile of the PRS distribution (Figure 1). 
medRxiv preprint doi: https://doi.org/10.1101/2021.08.13.21262050; this version posted August 23, 2021. The copyright holder for this preprint (which was not certified by peer review) is the author/funder, who has granted medRxiv a license to display the preprint in

It is made available under a CC-BY-NC-ND 4.0 International license .

Lifetime Risk for Breast Cancer Gene Carriers Stratified by PRS and Family History

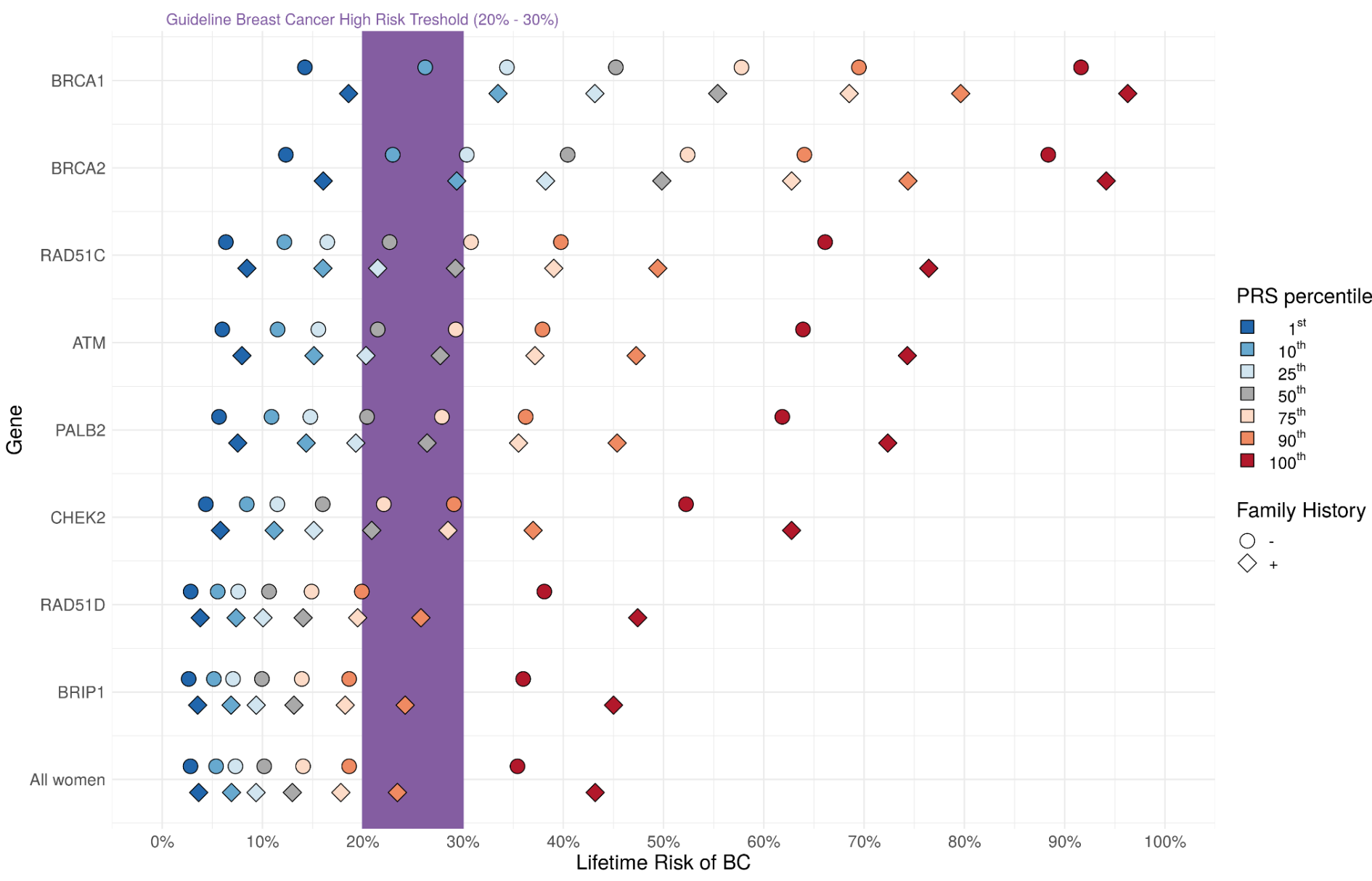

Figure 1: PRS modulates the penetrance of 8 BC susceptibility genes. We identified carriers of pathogenic variants in 8 breast cancer susceptibility genes in whole exome sequence data in 86,385 women in the UK Biobank. For each gene we show the predicted lifetime risk for carriers with (diamonds) and without (circles) family history across a range of different PRS percentiles using the Allelica 577k PRS. Data and confidence intervals are reported in Supplementary Tables 4 and 5 . The same analysis using the Mavaddat 313 SNP PRS ${ }^{17}$ is shown in the Supplementary Figure. An equivalent model without carrier status was built using All women in the PRS Testing dataset. Dashed lines show lifetime risk for percentiles of the Allelica $577 \mathrm{k}$ PRS distribution in Non-carriers. American Cancer Association guidelines state that a threshold of $20 \%$ lifetime risk equates to High Risk ${ }^{20}$. We estimated lifetime risk as risk of BC by age 79 with a Cox proportional hazards regression for each gene separately in a model that included case/control status, age of enrollment and age of disease in the survival function, and carrier status, PRS, 4 PCs and genotyping array as covariates.

Amongst carriers of LP/P variants, PRS stratified lifetime risk, extending recent studies demonstrating the modulation of penetrance by $\mathrm{BC} \mathrm{PRS}^{21,22}$ to a larger set of genes on a larger dataset. Approximately $11 \%(\mathrm{~N}=9,669)$ of the women in this dataset had family history of $\mathrm{BC}$ (defined as at least one first degree relative diagnosed with $\mathrm{BC}$ ) allowing for the additional stratification of risk in carriers with family history to be assessed. Lifetime risk of carriers of mutations in all 8 genes varied substantially on the basis of PRS (Figure 1). Family history provides additional information that modulates $\mathrm{BC}$ risk in combination with PRS. Whilst there is no universal definition of high risk for $\mathrm{BC}$, 
medRxiv preprint doi: https://doi.org/10.1101/2021.08.13.21262050; this version posted August 23, 2021. The copyright holder for this preprint (which was not certified by peer review) is the author/funder, who has granted medRxiv a license to display the preprint in It is made available under a CC-BY-NC-ND 4.0 International license

the American Cancer Society suggests a threshold for high risk of $20-25 \%$ lifetime risk ${ }^{20}$ and in the US lifetime risk of greater than $20 \%$ can lead to the initiation of screening with magnetic resonance imaging (MRI) ${ }^{23}$. Guidelines from the National Institute for Health and Care Excellence in the United Kingdom use two thresholds of risk: Moderate lifetime risk $17-30 \%$; and High lifetime risk $>30 \%^{24}$. Here we use a broad threshold of $20-30 \%$ as High risk. Carriers of LP/P mutations in BRCA1 in the lowest decile of the PRS distribution without family history have lifetime risk within this High risk threshold $(26 \% ; 95 \% \mathrm{Cl}: 9-43 \%)$, whereas those in the bottom decile with family history have a 1 in 3 lifetime risk of disease $(33 \%(95 \% \mathrm{Cl} 13 \%-54 \%)$. At the other end of the distribution, the combination of high polygenic and monogenic risk leads to $80 \%(95 \% \mathrm{Cl}$ : $55-100 \%))$ and $69 \%$ (95\% Cl: $43-96 \%)$ lifetime risk for women in the top decile of the PRS distribution, with and without family history respectively. Around half of LP/P mutation carriers in moderate penetrance genes (RAD51C, ATM and PALB2) will have an overall lifetime risk of less than $25 \%$. Conversely, women who carry mutations in these genes and in the top percentile of the PRS distribution have a greater than one in two lifetime risk of BC (Figure 1, Supplementary Tables 3 and 4). The effect of PRS on lifetime risk in carriers of variants in CHEK2, RAD51D and BRIP1 is modulated in a similar manner to non-carriers. Taken together, these results indicate that PRS provides additional information on the penetrance of mutations in $\mathrm{BC}$ susceptibility genes that can be used by patients and physicians to inform potential risk mitigation options.

We compiled a list of published Odds Ratios (ORs) for 8 BC susceptibility genes, together with their estimated prevalence and compared them with ORs for different strata of the Allelica 577k PRS distribution (Figure 2, Supplementary Table 5) ${ }^{11,12}$. ORs for BRCA1 carriers are the highest, ranging from point estimates of 7.62 to 10.57 . Odds Ratios for the top $0.5 \%$ of the Allelica $577 \mathrm{k}$ PRS distribution, BRCA2 and PALB2 mutation carriers are broadly similar (Figure 2) despite the prevalence of this PRS strata being double that of BRCA2 carriers (prevalence: $0.24-0.26 \%$ ) and over four times greater than PALB2 mutation carriers (prevalence: $0.10-0.12 \%$ ). PRS therefore identifies a greater number of women at high risk ( $5 \mathrm{X}$ increased risk) than carriers of variants in these genes. 
medRxiv preprint doi: https://doi.org/10.1101/2021.08.13.21262050; this version posted August 23, 2021. The copyright holder for this preprint (which was not certified by peer review) is the author/funder, who has granted medRxiv a license to display the preprint in perpetuity.

It is made available under a CC-BY-NC-ND 4.0 International license.

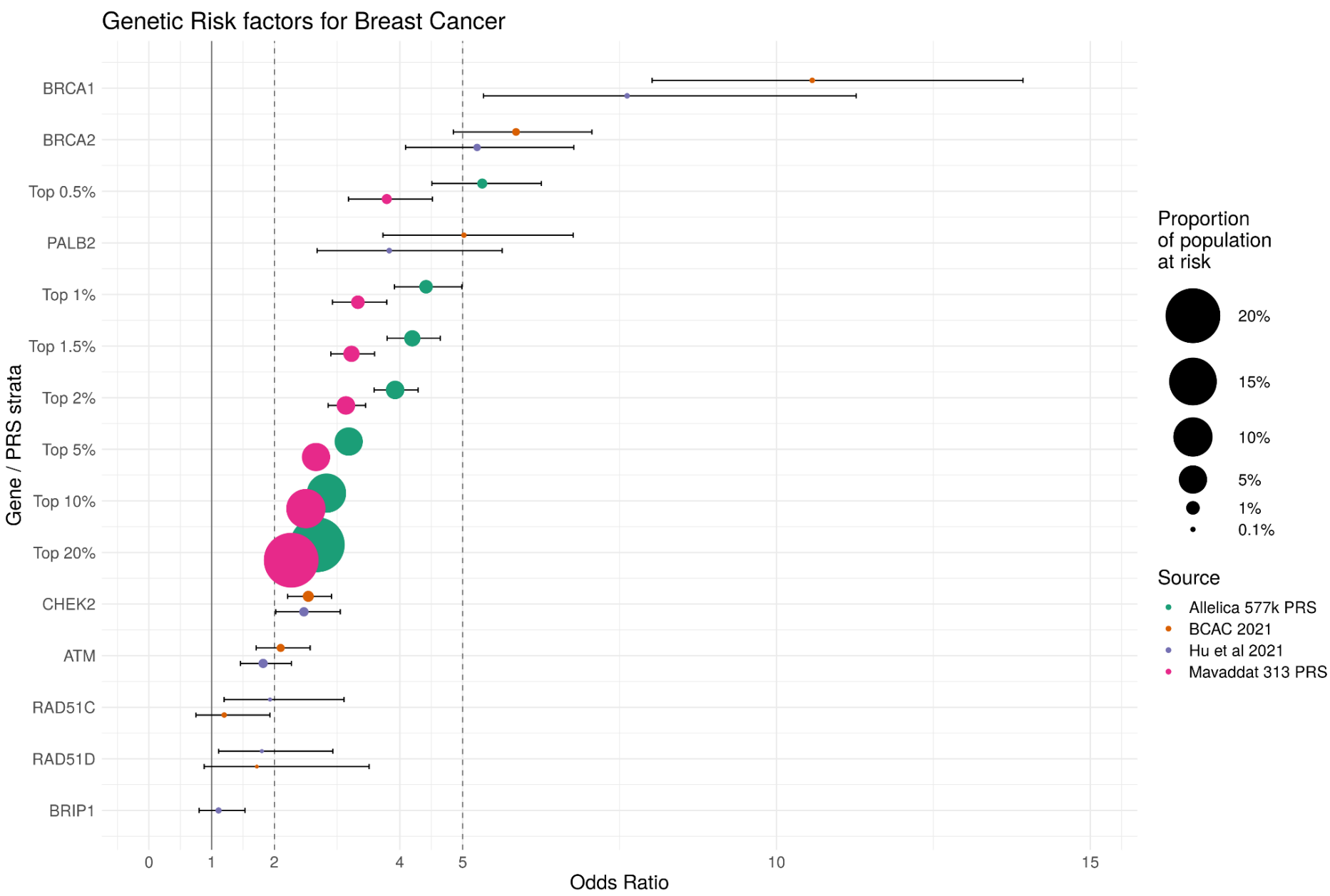

Figure 2: Genetic risk factors for breast cancer. For eight Breast Cancer susceptibility genes we show published estimates of ORs from two separate population-based studies (with the exception of BRIP1 in the BCAC 2021 study, which was not analysed). For comparison we show ORs for the top X\% for the PRS distribution for the Allelica 577k and Mavaddat 313 PRS, which were computed with logistic regression comparing individuals with a PRS in or above the percentile against the remainder of the PRS distribution controlling for the first four principal components of genetic ancestry and age of enrollment. The point size represents the proportion of the population at risk and reflects the number of individuals that have the genetic risk factor.

Genetic factors that increase risk by 2-4 times are considered to be moderate-risk ${ }^{9}$ PRS can identify one in five women (top 20\%) with an average genetic risk greater than $2 \quad(\mathrm{OR}=2.68(95 \% \mathrm{Cl}$ 2.57-2.78)), which is above that for carriers of mutations in ATM and equivalent to CHEK2 mutation carriers. By definition this strata contains $20 \%$ of the population, demonstrating the potential for PRS to identify women at both moderate and high genetic risk of $\mathrm{BC}$, who are up to 40 times more common in the population. Risk for women in the top $2 \%$ of the PRS distribution approaches four times $(3.92(95 \% \mathrm{Cl} 3.58-4.29))$ the average population risk. In addition to the Allelica 577k PRS, we also show ORs for PRS percentiles using the Mavaddat 313 SNP PRS ${ }^{17}$ (Supplementary Figure, Supplementary Table 5), which show a similar trend with less intense stratification. 
medRxiv preprint doi: https://doi.org/10.1101/2021.08.13.21262050; this version posted August 23, 2021. The copyright holder for this preprint (which was not certified by peer review) is the author/funder, who has granted medRxiv a license to display the preprint in It is made available under a CC-BY-NC-ND 4.0 International license

This study supports the hypothesis that common genetic variation controls the penetrance of pathogenic mutations in $B R C A 1$ and $B R C A 2^{25}$ as well as moderate penetrance genes. Together with information on pathogenic carrier status and family history, PRS has the potential to inform current screening approaches ${ }^{26}$. For example, $B R C A 1$ and $B R C A 2$ mutation carriers with no family history of $\mathrm{BC}$ who are in the lowest decile of the PRS distribution have a lower than 1 in three lifetime risk of BC, information that can be used to guide and potentially avoid invasive risk mitigation strategies involving surgery intervention such as mastectomy. Around half of carriers of mutations in moderate penetrance genes have a less than $20 \%$ lifetime risk of $B C$, whereas those with the highest PRS scores, for example in the top decile of the PRS distribution (Figure 1) have over double the lifetime risk ( 40\%). When combined with family history, this risk rises still further. In the absence of pathogenic mutations, PRS can identify $1 \%$ of women with a greater than 4 fold increased risk of BC (Figure 2). One strategy where PRS could have immediate utility is as an additional screening tool for women identified as high risk through other risk factors, such as family history ${ }^{23}$. Whilst family history is a robust predictor of breast cancer risk, one striking outcome of this present study is that women with rare pathogenic mutations and family history can have wildly different risk trajectories because of their polygenic risk. For example, lifetime risk for women with family history of BC who are carriers of a pathogenic mutation in BRCA2 varies from less than $30 \%$ in the bottom decile to almost $75 \%$ in the top decile of the PRS distribution (Supplementary Table 4).

This work has some limitations. First, our analyses are based on a European ancestry subset of the UK Biobank and results may translate differently across ancestries. PRS is not alone in having an ancestry bias: for example, the ability of the commonly used GAIL model to assess 5 year breast cancer varies in different ancestry groups ${ }^{27}$ and pathogenic founder mutations in $B R C A 1 / 2$ genes are under-represented in clinical databases ${ }^{28}$, meaning that screening for known variants is less effective in Non-European ancestry groups. As such, current guidelines on the clinical utility of these variants take a woman's ancestry into account. A similar approach can be taken with PRS, where well validated, ancestry-specific scores can be used when they outperform those developed on predominantly European ancestry datasets. We support all efforts to build ancestrally diverse datasets to ensure that genomic information can be used widely. Secondly, environmental factors contribute to a woman's risk ${ }^{29}$ which in the current context may include modulating the penetrance of $\mathrm{BC}$ mutations and the risk conferred by the PRS. Thirdly, despite utilising data from over 90 thousand exomes, 
medRxiv preprint doi: https://doi.org/10.1101/2021.08.13.21262050; this version posted August 23, 2021. The copyright holder for this preprint (which was not certified by peer review) is the author/funder, who has granted medRxiv a license to display the preprint in It is made available under a CC-BY-NC-ND 4.0 International license.

mutation carriers are rare (Supplementary Table 2). Larger datasets will allow for further granularity of the penetrance modulation estimates presented here.

Current guidelines do not include the use of PRS to assess clinical risk of BC. Whilst the benefits of assessing individuals for the presence of pathogenic mutations in $\mathrm{BC}$ susceptibility genes has undoubted utility in those that carry them, PRS provides fundamental and complementary information on the effect of these variants on the lifetime risk of disease that can be used to guide preventative strategies according to current guidelines. In addition, PRS identifies women at high genetic risk who are invisible to screening of rare pathogenic mutations. Without considering PRS in pathogenic mutation testing, about half of the carriers of mutations in moderate penetrance genes are incorrectly assigned as high risk, leading towards potentially unnecessary preventive measures. Even with a family history of breast cancer, around $10 \%$ of BRCA1 carriers have a 1 in 3 lifetime risk of BC. Whilst high enough to warrant active surveillance through mammographic screening and MRI, this risk level is not high enough to justify invasive, unnecessary and potentially harmful surgical intervention. For the $95 \%$ of women whose BC is not the result of rare pathogenic mutations, PRS offers a way to identify heightened risk, comparable to that conferred by monogenic mutations yet present in significantly more women. Combining information from both rare and common variation with family history paves the way for a targeted and data-driven approach to BC risk mitigation. 
medRxiv preprint doi: https://doi.org/10.1101/2021.08.13.21262050; this version posted August 23, 2021. The copyright holder for this preprint (which was not certified by peer review) is the author/funder, who has granted medRxiv a license to display the preprint in It is made available under a CC-BY-NC-ND 4.0 International license .

\section{Methods}

\section{Data}

This study utilises both the UK Biobank imputed genotype and whole exome sequence data under project number 40692. Full details of the UK Biobank resource have been described previously ${ }^{15}$. UK Biobank received ethical approval from the North West Multi-Center Research Ethics Committee (11/NW/03820). We used data from a subset of women self-identified as having White British ancestry $(\mathrm{N}=221,479)$ and further split this dataset to produce independent Validation and Testing datasets using the UK Biobank first release (genotyping batch from 11 to 22) and second release (genotyping batch from 23 to 95), respectively. Breast cancer phenotype information was collated by extracting data in the fields reported in Supplementary Table 1. The Validation dataset comprised 4,764 BC cases (1,811 incident / 2,953 prevalent) and 64,055 controls and the Testing dataset comprised 10,871 cases $(4,163$ incident / 6,708 prevalent) and 141,789 controls.

\section{Building a new PRS for Breast Cancer}

We applied the following algorithms to identify the PRS with the best predictive performance: Clumping and Thresholding ${ }^{30}$, Stacked Clumping and Thresholding ${ }^{16}$, LDPred2, LDPred2-Inf, LDPred-funct $^{31}$, Lassosum ${ }^{32}$, SBayesR ${ }^{33}$, PRS-CS, PRS-CS-auto ${ }^{34}$ and an ensemble score generated using machine learning (Support Vector Machine). PRS panels were developed using Training data (Genome Wide Association Study summary statistics) from Michaillidou et $\mathrm{al}^{13}$, and the separate Validation and Testing datasets outlined above. The score with the best predictive power (highest Area Under the Curve) in the Validation dataset used the Stacked Clumping and Thresholding algorithm and contained 577,113 genome-wide variants. AUC and Odds Ratio per Standard Deviation are reported in the Testing dataset.

\section{Classifying pathogenic variants}

We used the TAPES software ${ }^{35}$ to classify all variants in 90,307 women with self-identified White British ancestry from the UK Biobank whole exome sequence dataset. Of these 6,332 were BC cases (3,992 prevalent / 2,410 incident) and 83,975 were controls. All variants identified as Likely Pathogenic / Pathogenic (LP/P) according to ClinVar ${ }^{18}$ in each of the following 8 breast cancer 
medRxiv preprint doi: https://doi.org/10.1101/2021.08.13.21262050; this version posted August 23, 2021. The copyright holder for this preprint (which was not certified by peer review) is the author/funder, who has granted medRxiv a license to display the preprint in It is made available under a CC-BY-NC-ND 4.0 International license.

susceptibility genes were kept for further analysis: ATM, BRCA1, BRCA2, BRIP1, CHEK2, PALB2, RAD51C and RAD51D.

\section{Lifetime risk}

Lifetime risk of breast cancer was computed with Cox proportional hazards models using the coxph function from the survival package in $R^{36}$. The survival function contained breast cancer cases status (for incident cases and controls only) together with age of disease, age of enrollment. Standardised PRS, first four ancestry PCs and genotyping arrays were used as covariates together with carrier status where relevant. Lifetime risk was predicted by predicting survival by age 79 for each percentile of the PRS distribution using the riskRegression package in $R^{37}$. To account for non-normally distributed risk within PRS percentiles, lifetime risk was predicted for each $0.01 \%$ of the distribution and then averaged across a given percentile by fitting an exponential curve to the data within a percentile and finding the rate of this curve.

\section{Association testing}

We used the glm function in $\mathrm{R}$ to perform logistic regression to calculate odds ratios and $95 \%$ confidence intervals for top $\mathrm{X} \%$ of the PRS distribution. Breast cancer case status was predicted using an independent indicator variable for each individual's assignment to the top $\mathrm{X} \%$ of the PRS distribution (where $X=80,90,95,98,99,99.5$ ), and controlling for the first four ancestry PCs, genotyping array, age of enrollment.

\section{Acknowledgements}

We thank all participants in the UK Biobank. This work was funded by internal research and development funding from Allelica, Inc.

\section{Competing Interests}

All authors are employees at Allelica Inc. 
medRxiv preprint doi: https://doi.org/10.1101/2021.08.13.21262050; this version posted August 23, 2021. The copyright holder for this preprint (which was not certified by peer review) is the author/funder, who has granted medRxiv a license to display the preprint in It is made available under a CC-BY-NC-ND 4.0 International license .

\section{References}

1. Easton, D. F. et al. Gene-Panel Sequencing and the Prediction of Breast-Cancer Risk. http://dx.doi.org/10.1056/NEJMsr1501341 https://www.nejm.org/doi/10.1056/NEJMsr1501341 (2015) doi:10.1056/NEJMsr1501341.

2. Evans, D. G. et al. Penetrance estimates for BRCA1 and BRCA2based on genetic testing in a Clinical Cancer Genetics service setting: Risks of breast/ovarian cancer quoted should reflect the cancer burden in the family. BMC Cancer 8, 155 (2008).

3. Chen, S. \& Parmigiani, G. Meta-Analysis of BRCA1 and BRCA2 Penetrance. J. Clin. Oncol. Off. J. Am. Soc. Clin. Oncol. 25, 1329-1333 (2007).

4. Antoniou, A. C. et al. Breast-Cancer Risk in Families with Mutations in PALB2. N. Engl. J. Med. 371, 497-506 (2014).

5. Stolarova, L. et al. CHEK2 Germline Variants in Cancer Predisposition: Stalemate Rather than Checkmate. Cells 9, E2675 (2020).

6. Ahmed, M. \& Rahman, N. ATM and breast cancer susceptibility. Oncogene 25, 5906-5911 (2006).

7. Collaborative Group on Hormonal Factors in Breast Cancer. Familial breast cancer: collaborative reanalysis of individual data from 52 epidemiological studies including 58,209 women with breast cancer and 101,986 women without the disease. Lancet Lond. Engl. 358, 1389-1399 (2001).

8. Gao, C. et al. Risk of Breast Cancer Among Carriers of Pathogenic Variants in Breast Cancer Predisposition Genes Varies by Polygenic Risk Score. J. Clin. Oncol. 39, 2564-2573 (2021).

9. Wendt, C. \& Margolin, S. Identifying breast cancer susceptibility genes - a review of the genetic background in familial breast cancer. Acta Oncol. 58, 135-146 (2019).

10. Mavaddat, N., Antoniou, A. C., Easton, D. F. \& Garcia-Closas, M. Genetic susceptibility to breast cancer. Mol. Oncol. 4, 174-191 (2010).

11. Hu, C. et al. A Population-Based Study of Genes Previously Implicated in Breast Cancer. N. Engl. J. Med. 384, 440-451 (2021).

12. Breast Cancer Risk Genes - Association Analysis in More than 113,000 Women. N. Engl. J. Med. 384, 428-439 (2021).

13. Michailidou, K. et al. Association analysis identifies 65 new breast cancer risk loci. Nature 551, 92-94 (2017). 
medRxiv preprint doi: https://doi.org/10.1101/2021.08.13.21262050; this version posted August 23, 2021. The copyright holder for this preprint (which was not certified by peer review) is the author/funder, who has granted medRxiv a license to display the preprint in It is made available under a CC-BY-NC-ND 4.0 International license .

14. Bolli, A., Domenico, P. D. \& Bottà, G. Software as a Service for the Genomic Prediction of Complex Diseases. bioRxiv 763722 (2019) doi:10.1101/763722.

15. Bycroft, C. et al. The UK Biobank resource with deep phenotyping and genomic data. Nature $\mathbf{5 6 2}$, 203-209 (2018).

16. Privé, F., Vilhjálmsson, B. J., Aschard, H. \& Blum, M. G. B. Making the Most of Clumping and Thresholding for Polygenic Scores. Am. J. Hum. Genet. 105, 1213-1221 (2019).

17. Mavaddat, N. et al. Polygenic Risk Scores for Prediction of Breast Cancer and Breast Cancer Subtypes. Am. J. Hum. Genet. 104, 21-34 (2019).

18. Landrum, M. J. et al. ClinVar: improvements to accessing data. Nucleic Acids Res. 48, D835-D844 (2020).

19. Szustakowski, J. D. et al. Advancing Human Genetics Research and Drug Discovery through Exome Sequencing of the UK Biobank. medRxiv 2020.11.02.20222232 (2020) doi:10.1101/2020.11.02.20222232.

20. ACS Breast Cancer Early Detection Recommendations. https://www.cancer.org/cancer/breast-cancer/screening-tests-and-early-detection/american-cance r-society-recommendations-for-the-early-detection-of-breast-cancer.html.

21. Fahed, A. C. et al. Polygenic background modifies penetrance of monogenic variants for tier 1 genomic conditions. Nat. Commun. 11, 3635 (2020).

22. Mars, N. et al. The role of polygenic risk and susceptibility genes in breast cancer over the course of life. Nat. Commun. 11, 6383 (2020).

23. Shah, P. D. Polygenic Risk Scores for Breast Cancer-Can They Deliver on the Promise of Precision Medicine? JAMA Netw. Open 4, e2119333-e2119333 (2021).

24. How breast cancer risk is described | Information for the public | Familial breast cancer: classification, care and managing breast cancer and related risks in people with a family history of breast cancer | Guidance | NICE. https://www.nice.org.uk/guidance/cg164/ifp/chapter/how-breast-cancer-risk-is-described.

25. Downs, B. et al. Common genetic variants contribute to incomplete penetrance: evidence from cancer-free BRCA1 mutation carriers. Eur. J. Cancer Oxf. Engl. 1990 107, 68-78 (2019).

26. Yanes, T., Young, M.-A., Meiser, B. \& James, P. A. Clinical applications of polygenic breast cancer risk: a critical review and perspectives of an emerging field. Breast Cancer Res. 22, 21 (2020). 
medRxiv preprint doi: https://doi.org/10.1101/2021.08.13.21262050; this version posted August 23, 2021. The copyright holder for this preprint (which was not certified by peer review) is the author/funder, who has granted medRxiv a license to display the preprint in It is made available under a CC-BY-NC-ND 4.0 International license .

27. Wang, X. et al. Assessment of performance of the Gail model for predicting breast cancer risk: a systematic review and meta-analysis with trial sequential analysis. Breast Cancer Res. BCR 20, $18(2018)$.

28. Abul-Husn, N. S. et al. Exome sequencing reveals a high prevalence of BRCA1 and BRCA2 founder variants in a diverse population-based biobank. Genome Med. 12, 2 (2019).

29. Al Ajmi, K., Lophatananon, A., Mekli, K., Ollier, W. \& Muir, K. R. Association of Nongenetic Factors With Breast Cancer Risk in Genetically Predisposed Groups of Women in the UK Biobank Cohort. JAMA Netw. Open 3, e203760 (2020).

30. Wray, N. R., Goddard, M. E. \& Visscher, P. M. Prediction of individual genetic risk to disease from genome-wide association studies. Genome Res. 17, 1520-1528 (2007).

31. Privé, F., Arbel, J. \& Vilhjálmsson, B. J. LDpred2: better, faster, stronger. Bioinformatics (2020) doi:10.1093/bioinformatics/btaa1029.

32. Mak, T. S. H., Porsch, R. M., Choi, S. W., Zhou, X. \& Sham, P. C. Polygenic scores via penalized regression on summary statistics. Genet. Epidemiol. 41, 469-480 (2017).

33. Lloyd-Jones, L. R. et al. Improved polygenic prediction by Bayesian multiple regression on summary statistics. Nat. Commun. 10, 5086 (2019).

34. Ge, T., Chen, C.-Y., Ni, Y., Feng, Y.-C. A. \& Smoller, J. W. Polygenic prediction via Bayesian regression and continuous shrinkage priors. Nat. Commun. 10, 1776 (2019).

35. Xavier, A., Scott, R. J. \& Talseth-Palmer, B. A. TAPES: A tool for assessment and prioritisation in exome studies. PLOS Comput. Biol. 15, e1007453 (2019).

36. Therneau, T. M. A package for survival analysis in $r$. https://CRAN.R-project.org/package=survival (2021).

37. Ozenne, B., Sørensen, A. L., Scheike, T., Torp-Pedersen, C. \& Gerds, T. A. riskRegression: Predicting the Risk of an Event using Cox Regression Models. R J. 9, 440-460 (2017). 


\section{Supplementary Material}

Supplementary Table 1: UK Biobank codes used to define breast cancer phenotypes used in this study

\begin{tabular}{|c|c|c|}
\hline \multicolumn{3}{|c|}{ Breast Cancer (BC) } \\
\hline UK BioBank Field & Description & Codes \\
\hline 20001 & Self reported cancer code & 1002 \\
\hline 41202 & Diagnoses -main ICD10 & \multirow{5}{*}{$\begin{array}{l}\text { C500-C509, } \\
\text { D050-D051, } \\
\text { D057,D059 }\end{array}$} \\
\hline 41204 & Diagnoses -Secondary ICD10 & \\
\hline 40001 & $\begin{array}{l}\text { Underlying cause of death - } \\
\text { ICD10 }\end{array}$ & \\
\hline 40002 & $\begin{array}{l}\text { Contributory causes of death - } \\
\qquad \text { ICD10 }\end{array}$ & \\
\hline 40006 & Type of cancer - ICD10 & \\
\hline
\end{tabular}


medRxiv preprint doi: https://doi.org/10.1101/2021.08.13.21262050; this version posted August 23, 2021. The copyright holder for this preprint (which was not certified by peer review) is the author/funder, who has granted medRxiv a license to display the preprint in It is made available under a CC-BY-NC-ND 4.0 International license.

Supplementary Table 2: Number of carriers of pathogenic mutations in 86,385 women in the UK Biobank. The number of carriers of likely pathogenic or pathogenic variants (L/LP) according to ClinVar. The number of unique variants in each gene as well as the number of cases who are carriers is also shown. This analysis was conducted on incident BC cases only.

\begin{tabular}{|c|c|c|c|}
\hline Gene & $\begin{array}{c}\text { Num. } \\
\text { carriers }\end{array}$ & $\begin{array}{c}\text { Num. unique } \\
\text { variants }\end{array}$ & Num. cases \\
\hline BRCA1 & 46 & 32 & 7 \\
\hline BRCA2 & 210 & 105 & 27 \\
\hline RAD51C & 32 & 14 & 2 \\
\hline ATM & 261 & 101 & 17 \\
\hline PALB2 & 77 & 30 & 5 \\
\hline CHEK2 & 119 & 24 & 5 \\
\hline RAD51D & 35 & 9 & 1 \\
\hline BRIP1 & 104 & 31 & 3 \\
\hline Total & $\mathbf{8 8 4}$ & $\mathbf{3 4 6}$ & $\mathbf{6 7}$ \\
\hline
\end{tabular}

Supplementary Table 3: Number of carriers of pathogenic mutations in 3,922 women in the UK Biobank with prevalent breast cancer (i.e. before enrollment in the UK Biobank). The number of carriers of likely pathogenic or pathogenic variants (L/LP) according to ClinVar. The number of unique variants in each gene as well as the number of cases who are carriers is also shown. These individuals were removed from the association analyses in this study.

\begin{tabular}{|c|c|c|c|}
\hline Gene & $\begin{array}{c}\text { Num. } \\
\text { carriers }\end{array}$ & $\begin{array}{c}\text { Num. unique } \\
\text { variants }\end{array}$ & Num. cases \\
\hline BRCA1 & 25 & 24 & 25 \\
\hline BRCA2 & 56 & 43 & 56 \\
\hline RAD51C & 1 & 1 & 1 \\
\hline ATM & 36 & 27 & 36 \\
\hline PALB2 & 7 & 7 & 7 \\
\hline CHEK2 & 9 & 4 & 9 \\
\hline RAD51D & 4 & 4 & 4 \\
\hline BRIP1 & 9 & 7 & 9 \\
\hline Total & $\mathbf{1 4 7}$ & $\mathbf{1 1 7}$ & $\mathbf{1 4 7}$ \\
\hline
\end{tabular}


medRxiv preprint doi: https://doi.org/10.1101/2021.08.13.21262050; this version posted August 23, 2021. The copyright holder for this preprint (which was not certified by peer review) is the author/funder, who has granted medRxiv a license to display the preprint in

It is made available under a CC-BY-NC-ND 4.0 International license .

Supplementary Table 4: Predicted Lifetime risk (risk by age 79 ) and $95 \%$ confidence intervals for carriers of pathogenic mutations without family history of breast cancer at different PRS strata using the Allelica 577k and Mavaddat 313.

\begin{tabular}{|c|c|c|c|c|c|c|}
\hline Gene & $\begin{array}{c}\text { PRS } \\
\text { percentile }\end{array}$ & $\begin{array}{l}\text { Lifetime Risk } \\
\text { (Allelica 577k) }\end{array}$ & $\begin{array}{c}\text { Lifetime Risk } \\
\text { (Mavaddat 313) }\end{array}$ & Gene & $\begin{array}{c}\text { Lifetime Risk } \\
\text { (Allelica 577k) }\end{array}$ & $\begin{array}{c}\text { Lifetime Risk } \\
\text { (Mavaddat 313) }\end{array}$ \\
\hline BRCA1 & 1 & $0.14(0.04-0.24)$ & $0.17(0.05-0.29)$ & CHEK2 & $0.04(0.01-0.08)$ & $0.05(0.01-0.09)$ \\
\hline BRCA1 & 10 & $0.26(0.09-0.43)$ & $0.29(0.1-0.47)$ & CHEK2 & $0.08(0.01-0.15)$ & $0.09(0.01-0.16)$ \\
\hline BRCA1 & 25 & $0.34(0.14-0.55)$ & $0.36(0.14-0.58)$ & CHEK2 & $0.11(0.02-0.21)$ & $0.11(0.02-0.21)$ \\
\hline BRCA1 & 50 & $0.45(0.21-0.7)$ & $0.45(0.21-0.7)$ & CHEK2 & $0.16(0.03-0.29)$ & $0.15(0.03-0.28)$ \\
\hline BRCA1 & 75 & $0.58(0.31-0.85)$ & $0.56(0.29-0.83)$ & CHEK2 & $0.22(0.05-0.39)$ & $0.2(0.04-0.36)$ \\
\hline BRCA1 & 90 & $0.69(0.43-0.96)$ & $0.66(0.38-0.93)$ & CHEK2 & $0.29(0.08-0.5)$ & $0.25(0.06-0.45)$ \\
\hline BRCA1 & 100 & $0.92(0.77-1)$ & $0.87(0.67-1)$ & CHEK2 & $0.52(0.22-0.83)$ & $0.43(0.15-0.71)$ \\
\hline BRCA2 & 1 & $0.12(0.08-0.17)$ & $0.15(0.09-0.21)$ & RAD51D & $0.03(0-0.08)$ & $0.04(0-0.11)$ \\
\hline BRCA2 & 10 & $0.23(0.15-0.31)$ & $0.25(0.16-0.34)$ & RAD51D & $0.06(0-0.16)$ & $0.06(0-0.19)$ \\
\hline BRCA2 & 25 & $0.3(0.2-0.4)$ & $0.32(0.21-0.42)$ & RAD51D & $0.08(0-0.22)$ & $0.08(0-0.24)$ \\
\hline BRCA2 & 50 & $0.4(0.28-0.53)$ & $0.41(0.28-0.53)$ & RAD51D & $0.11(0-0.31)$ & $0.11(0-0.32)$ \\
\hline BRCA2 & 75 & $0.52(0.38-0.66)$ & $0.51(0.37-0.64)$ & RAD51D & $0.15(0-0.42)$ & $0.15(0-0.41)$ \\
\hline BRCA2 & 90 & $0.64(0.49-0.79)$ & $0.6(0.46-0.75)$ & RAD51D & $0.2(0-0.55)$ & $0.19(0-0.52)$ \\
\hline BRCA2 & 100 & $0.88(0.79-0.98)$ & $0.83(0.7-0.95)$ & RAD51D & $0.38(0-0.97)$ & $0.33(0-0.86)$ \\
\hline RAD51C & 1 & $0.06(0-0.15)$ & $0.08(0-0.19)$ & BRIP1 & $0.03(0-0.06)$ & $0.03(0-0.07)$ \\
\hline RAD51C & 10 & $0.12(0-0.29)$ & $0.14(0-0.32)$ & BRIP1 & $0.05(0-0.11)$ & $0.06(0-0.13)$ \\
\hline RAD51C & 25 & $0.16(0-0.38)$ & $0.18(0-0.41)$ & BRIP1 & $0.07(0-0.15)$ & $0.08(0-0.17)$ \\
\hline RAD51C & 50 & $0.23(0-0.51)$ & $0.23(0-0.53)$ & BRIP1 & $0.1(0-0.21)$ & $0.11(0-0.22)$ \\
\hline RAD51C & 75 & $0.31(0-0.67)$ & $0.3(0-0.66)$ & BRIP1 & $0.14(0-0.29)$ & $0.14(0-0.29)$ \\
\hline RAD51C & 90 & $0.4(0-0.84)$ & $0.38(0-0.8)$ & BRIP1 & $0.19(0-0.38)$ & $0.18(0-0.36)$ \\
\hline RAD51C & 100 & $0.66(0.14-1)$ & $0.59(0.08-1)$ & BRIP1 & $0.36(0.04-0.68)$ & $0.32(0.02-0.61)$ \\
\hline ATM & 1 & $0.06(0.03-0.09)$ & $0.08(0.04-0.11)$ & All women & $0.03(0.02-0.03)$ & $0.04(0.03-0.04)$ \\
\hline ATM & 10 & $0.12(0.06-0.17)$ & $0.13(0.07-0.19)$ & All women & $0.05(0.05-0.06)$ & $0.06(0.05-0.07)$ \\
\hline ATM & 25 & $0.16(0.08-0.23)$ & $0.17(0.09-0.25)$ & All women & $0.07(0.06-0.08)$ & $0.08(0.07-0.09)$ \\
\hline ATM & 50 & $0.21(0.12-0.31)$ & $0.22(0.13-0.32)$ & All women & $0.1(0.09-0.11)$ & $0.11(0.09-0.12)$ \\
\hline ATM & 75 & $0.29(0.17-0.41)$ & $0.29(0.17-0.41)$ & All women & $0.14(0.13-0.15)$ & $0.14(0.12-0.15)$ \\
\hline ATM & 90 & $0.38(0.23-0.52)$ & $0.36(0.22-0.5)$ & All women & $0.19(0.17-0.21)$ & $0.18(0.16-0.19)$ \\
\hline ATM & 100 & $0.64(0.46-0.82)$ & $0.57(0.39-0.75)$ & All women & $0.35(0.32-0.39)$ & $0.31(0.27-0.34)$ \\
\hline PALB2 & 1 & $0.06(0.01-0.1)$ & $0.07(0.01-0.13)$ & & & \\
\hline PALB2 & 10 & $0.11(0.02-0.2)$ & $0.12(0.02-0.22)$ & & & \\
\hline PALB2 & 25 & $0.15(0.03-0.27)$ & $0.15(0.03-0.28)$ & & & \\
\hline PALB2 & 50 & $0.2(0.05-0.36)$ & $0.2(0.04-0.36)$ & & & \\
\hline PALB2 & 75 & $0.28(0.07-0.48)$ & $0.26(0.07-0.46)$ & & & \\
\hline PALB2 & 90 & $0.36(0.11-0.61)$ & $0.33(0.09-0.56)$ & & & \\
\hline PALB2 & 100 & $0.62(0.3-0.93)$ & $0.53(0.22-0.84)$ & & & \\
\hline
\end{tabular}


medRxiv preprint doi: https://doi.org/10.1101/2021.08.13.21262050; this version posted August 23, 2021. The copyright holder for this preprint (which was not certified by peer review) is the author/funder, who has granted medRxiv a license to display the preprint in

It is made available under a CC-BY-NC-ND 4.0 International license .

Supplementary Table 5: Predicted Lifetime risk (risk by age 79 ) and $95 \%$ confidence intervals for carriers of pathogenic mutations with family history of breast cancer at different PRS strata using the Allelica 577k and Mavaddat 313.

\begin{tabular}{|c|c|c|c|c|c|c|}
\hline Gene & $\begin{array}{c}\text { PRS } \\
\text { percentile }\end{array}$ & $\begin{array}{l}\text { Lifetime Risk } \\
\text { (Allelica 577k) }\end{array}$ & $\begin{array}{l}\text { Lifetime Risk } \\
\text { (Mavaddat 313) }\end{array}$ & Gene & $\begin{array}{l}\text { Lifetime Risk } \\
\text { (Allelica 577k) }\end{array}$ & $\begin{array}{l}\text { Lifetime Risk } \\
\text { (Mavaddat 313) }\end{array}$ \\
\hline BRCA1 & 1 & $0.19(0.06-0.31)$ & $0.23(0.08-0.39)$ & CHEK2 & $0.06(0.01-0.11)$ & $0.07(0.01-0.13)$ \\
\hline BRCA1 & 10 & $0.33(0.13-0.54)$ & $0.38(0.15-0.6)$ & CHEK2 & $0.11(0.02-0.2)$ & $0.12(0.02-0.22)$ \\
\hline BRCA1 & 25 & $0.43(0.19-0.67)$ & $0.46(0.21-0.72)$ & CHEK2 & $0.15(0.03-0.27)$ & $0.16(0.03-0.29)$ \\
\hline BRCA1 & 50 & $0.55(0.28-0.82)$ & $0.57(0.3-0.84)$ & CHEK2 & $0.21(0.05-0.37)$ & $0.21(0.04-0.37)$ \\
\hline BRCA1 & 75 & $0.69(0.41-0.96)$ & $0.68(0.41-0.95)$ & CHEK2 & $0.28(0.08-0.49)$ & $0.27(0.06-0.47)$ \\
\hline BRCA1 & 90 & $0.8(0.55-1)$ & $0.78(0.52-1)$ & CHEK2 & $0.37(0.11-0.62)$ & $0.34(0.09-0.58)$ \\
\hline BRCA1 & 100 & $0.96(0.87-1)$ & $0.94(0.81-1)$ & CHEK2 & $0.63(0.31-0.95)$ & $0.54(0.23-0.86)$ \\
\hline BRCA2 & 1 & $0.16(0.1-0.22)$ & $0.2(0.12-0.28)$ & RAD51D & $0.04(0-0.11)$ & $0.05(0-0.15)$ \\
\hline BRCA2 & 10 & $0.29(0.19-0.39)$ & $0.33(0.22-0.44)$ & RAD51D & $0.07(0-0.22)$ & $0.09(0-0.25)$ \\
\hline BRCA2 & 25 & $0.38(0.26-0.5)$ & $0.41(0.29-0.54)$ & RAD51D & $0.1(0-0.29)$ & $0.11(0-0.33)$ \\
\hline BRCA2 & 50 & $0.5(0.36-0.64)$ & $0.51(0.37-0.66)$ & RAD51D & $0.14(0-0.4)$ & $0.15(0-0.43)$ \\
\hline BRCA2 & 75 & $0.63(0.48-0.77)$ & $0.62(0.48-0.77)$ & RAD51D & $0.19(0-0.55)$ & $0.2(0-0.55)$ \\
\hline BRCA2 & 90 & $0.74(0.6-0.88)$ & $0.72(0.58-0.87)$ & RAD51D & $0.26(0-0.7)$ & $0.25(0-0.68)$ \\
\hline BRCA2 & 100 & $0.94(0.88-1)$ & $0.91(0.82-1)$ & RAD51D & $0.47(0-1)$ & $0.42(0-1)$ \\
\hline RAD51C & 1 & $0.08(0-0.2)$ & $0.11(0-0.26)$ & BRIP1 & $0.04(0-0.08)$ & $0.05(0-0.1)$ \\
\hline RAD51C & 10 & $0.16(0-0.37)$ & $0.19(0-0.43)$ & BRIP1 & $0.07(0-0.14)$ & $0.08(0-0.18)$ \\
\hline RAD51C & 25 & $0.21(0-0.49)$ & $0.24(0-0.54)$ & BRIP1 & $0.09(0-0.2)$ & $0.11(0-0.23)$ \\
\hline RAD51C & 50 & $0.29(0-0.64)$ & $0.31(0-0.68)$ & BRIP1 & $0.13(0-0.27)$ & $0.14(0-0.3)$ \\
\hline RAD51C & 75 & $0.39(0-0.82)$ & $0.4(0-0.83)$ & BRIP1 & $0.18(0-0.37)$ & $0.19(0-0.39)$ \\
\hline RAD51C & 90 & $0.49(0-0.99)$ & $0.48(0-0.97)$ & BRIP1 & $0.24(0-0.48)$ & $0.24(0-0.48)$ \\
\hline RAD51C & 100 & $0.76(0.29-1)$ & $0.72(0.21-1)$ & BRIP1 & $0.45(0.08-0.82)$ & $0.41(0.06-0.77)$ \\
\hline ATM & 1 & $0.08(0.04-0.12)$ & $0.1(0.05-0.15)$ & All women & $0.04(0.03-0.04)$ & $0.05(0.04-0.05)$ \\
\hline ATM & 10 & $0.15(0.08-0.22)$ & $0.18(0.1-0.26)$ & All women & $0.07(0.06-0.08)$ & $0.08(0.07-0.09)$ \\
\hline ATM & 25 & $0.2(0.11-0.29)$ & $0.23(0.13-0.33)$ & All women & $0.09(0.08-0.11)$ & $0.1(0.09-0.12)$ \\
\hline ATM & 50 & $0.28(0.16-0.39)$ & $0.3(0.17-0.42)$ & All women & $0.13(0.11-0.15)$ & $0.14(0.12-0.16)$ \\
\hline ATM & 75 & $0.37(0.23-0.52)$ & $0.38(0.23-0.52)$ & All women & $0.18(0.16-0.2)$ & $0.18(0.16-0.2)$ \\
\hline ATM & 90 & $0.47(0.31-0.64)$ & $0.46(0.3-0.63)$ & All women & $0.23(0.21-0.26)$ & $0.23(0.2-0.25)$ \\
\hline ATM & 100 & $0.74(0.57-0.91)$ & $0.69(0.51-0.87)$ & All women & $0.43(0.39-0.48)$ & $0.38(0.34-0.43)$ \\
\hline PALB2 & 1 & $0.08(0.01-0.14)$ & $0.09(0.01-0.17)$ & & & \\
\hline PALB2 & 10 & $0.14(0.03-0.26)$ & $0.16(0.03-0.29)$ & & & \\
\hline PALB2 & 25 & $0.19(0.04-0.34)$ & $0.21(0.05-0.37)$ & & & \\
\hline PALB2 & 50 & $0.26(0.07-0.46)$ & $0.27(0.07-0.47)$ & & & \\
\hline PALB2 & 75 & $0.36(0.11-0.6)$ & $0.35(0.1-0.59)$ & & & \\
\hline PALB2 & 90 & $0.45(0.17-0.74)$ & $0.43(0.15-0.7)$ & & & \\
\hline PALB2 & 100 & $0.72(0.42-1)$ & $0.65(0.33-0.97)$ & & & \\
\hline
\end{tabular}


medRxiv preprint doi: https://doi.org/10.1101/2021.08.13.21262050; this version posted August 23, 2021. The copyright holder for this preprint (which was not certified by peer review) is the author/funder, who has granted medRxiv a license to display the preprint in It is made available under a CC-BY-NC-ND 4.0 International license.

Supplementary Table 6: Odds Ratios for carriers of pathogenic mutations in 8 BC susceptibility genes and top strata of the Allelica $577 \mathrm{k}$ and Mavaddat 313 SNP PRS.

\begin{tabular}{|c|c|c|c|}
\hline $\begin{array}{c}\text { Gene / PRS } \\
\text { strata }\end{array}$ & Odds Ratios $(95 \% \mathrm{Cl})$ & $\begin{array}{l}\text { Population } \\
\text { Freq. }\end{array}$ & Source \\
\hline BRCA1 & $10.57(8.02-13.93)$ & 0.114 & BCAC 2021 \\
\hline BRCA2 & $5.85(4.85-7.06)$ & 0.266 & BCAC 2021 \\
\hline PALB2 & $5.02(3.73-6.76)$ & 0.108 & BCAC 2021 \\
\hline CHEK2 & $2.54(2.21-2.91)$ & 0.621 & BCAC 2021 \\
\hline ATM & $2.1(1.71-2.57)$ & 0.296 & BCAC 2021 \\
\hline RAD51D & $1.72(0.88-3.51)$ & 0.04 & BCAC 2021 \\
\hline RAD51C & $1.2(0.75-1.93)$ & 0.11 & BCAC 2021 \\
\hline BRCA1 & $7.62(5.33-11.27)$ & 0.11 & Hu et al 2021 \\
\hline BRCA2 & $5.23(4.09-6.77)$ & 0.24 & Hu et al 2021 \\
\hline PALB2 & $3.83(2.68-5.63)$ & 0.12 & Hu et al 2021 \\
\hline CHEK2 & $2.47(2.02-3.05)$ & 0.42 & Hu et al 2021 \\
\hline RAD51C & $1.93(1.2-3.11)$ & 0.05 & Hu et al 2021 \\
\hline ATM & $1.82(1.46-2.27)$ & 0.41 & Hu et al 2021 \\
\hline RAD51D & $1.8(1.11-2.93)$ & 0.05 & Hu et al 2021 \\
\hline BRIP1 & $1.11(0.8-1.53)$ & 0.15 & Hu et al 2021 \\
\hline Top $0.5 \%$ & $5.311(4.511-6.254)$ & 0.5 & Allelica 577k PRS \\
\hline Top 1\% & $4.417(3.913-4.986)$ & 1 & Allelica 577k PRS \\
\hline Top $1.5 \%$ & $4.197(3.795-4.643)$ & 1.5 & Allelica 577k PRS \\
\hline Top 2\% & $3.924(3.588-4.291)$ & 2 & Allelica 577k PRS \\
\hline Top 5\% & $3.184(2.99-3.391)$ & 5 & Allelica 577k PRS \\
\hline Top 10\% & $2.83(2.693-2.974)$ & 10 & Allelica 577k PRS \\
\hline Top 20\% & $2.684(2.575-2.798)$ & 20 & Allelica 577k PRS \\
\hline Top $0.5 \%$ & $3.79(3.18-4.518)$ & 0.5 & Mavaddat 313 PRS \\
\hline Top 1\% & $3.33(2.925-3.792)$ & 1 & Mavaddat 313 PRS \\
\hline Top 1.5\% & $3.228(2.899-3.595)$ & 1.5 & Mavaddat 313 PRS \\
\hline Top 2\% & $3.139(2.855-3.452)$ & 2 & Mavaddat 313 PRS \\
\hline Top 5\% & $2.663(2.493-2.844)$ & 5 & Mavaddat 313 PRS \\
\hline Top $10 \%$ & $2.502(2.377-2.632)$ & 10 & Mavaddat 313 PRS \\
\hline Top 20\% & $2.268(2.174-2.365)$ & 20 & Mavaddat 313 PRS \\
\hline
\end{tabular}


medRxiv preprint doi: https://doi.org/10.1101/2021.08.13.21262050; this version posted August 23, 2021. The copyright holder for this preprint (which was not certified by peer review) is the author/funder, who has granted medRxiv a license to display the preprint in perpetuity.

It is made available under a CC-BY-NC-ND 4.0 International license

Lifetime Risk for Breast Cancer Gene Carriers Stratified by PRS

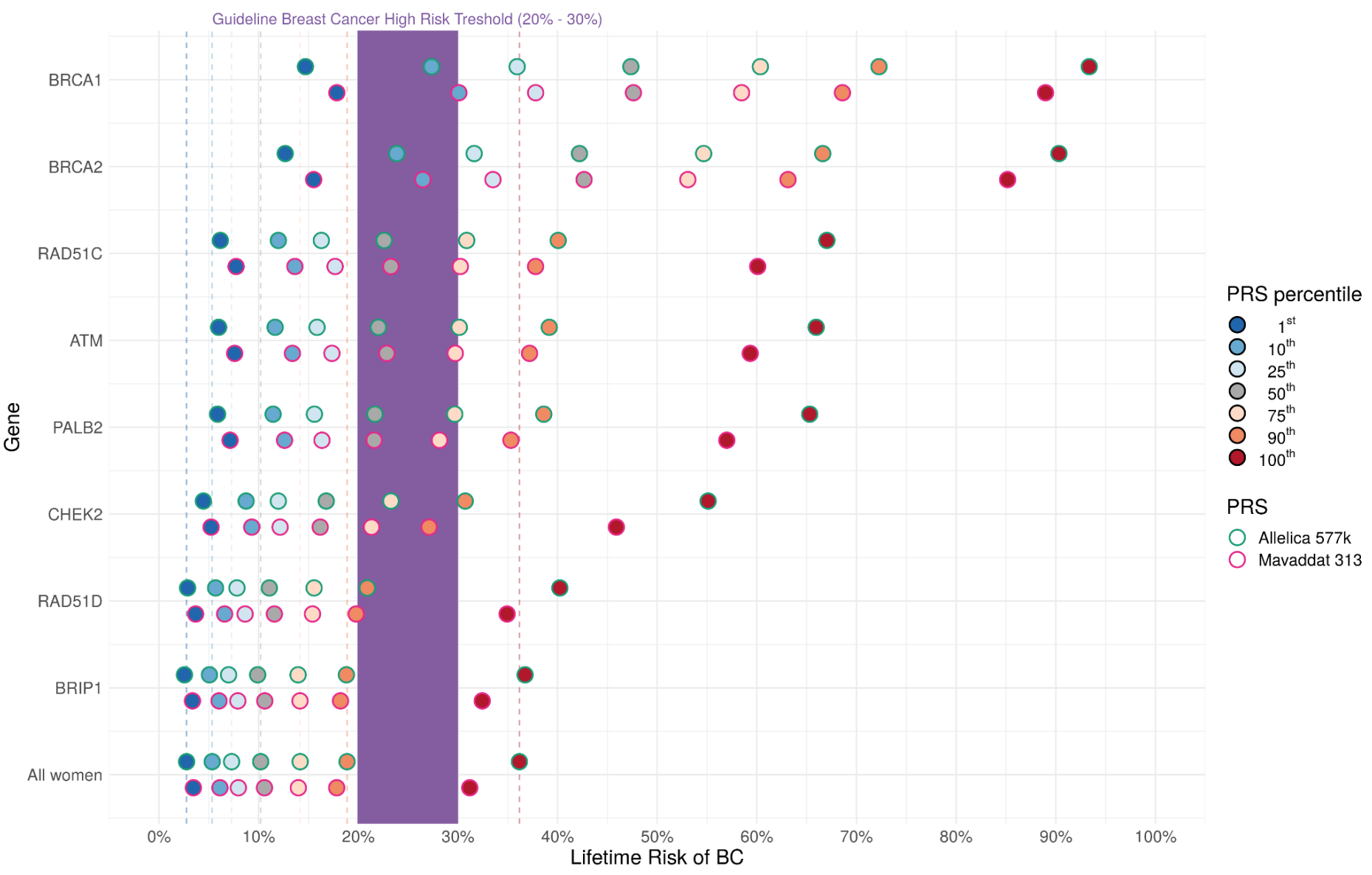

Supplementary Figure: PRS modulates the penetrance of 8 BC susceptibility genes. As Figure 1 with the inclusion of percentiles of the Mavaddat 313 SNP PRS ${ }^{17}$. We identified carriers of pathogenic variants in 8 breast cancer susceptibility genes in whole exome sequence data in 86,385 women in the UK Biobank. For each gene we show the predicted lifetime risk for carriers across a range of different PRS percentiles for the Allelica 577k PRS. An equivalent model without carrier status was built using all Non carriers (Non carriers). Dashed lines show lifetime risk for percentiles of the Allelica 577k PRS distribution in Non-carriers. American Cancer Association guidelines state that a threshold of $20 \%$ lifetime risk equates to High Risk ${ }^{20}$. We estimated lifetime risk of $B C$ with a Cox proportional hazards regression for each gene separately in a model that included case/control status, age of enrollment and age of disease in the survival function, and carrier status, PRS, 4 PCs and genotyping array as covariates. 